\title{
REFLEKSI SIMBOLIS KAPAL TERHADAP PERADABAN MASYARAKAT DESA BENGKAWAN DALAM SENI LUKIS
}

\author{
Riwanda Tamara \\ Program Penciptaan dan Pengkajian \\ Pascasarjana Institut Seni Indonesia Yogyakarta \\ e-mail : riwandax@gmail.com \\ Diterima : 10 Agustus 202ㅁ․ Disetujui : $2 \underline{5}$ November 2020. Dipublikasikan : 1 Desember 2020 \\ cC) (7) $\begin{aligned} & \text { (C) } 2020-\text { DESKOVI Universitas Maarif Hasyim Latif. Ini adalah artikel dengan akses } \\ & \text { terbuka di bawah lisensi CC BY } 4.0 \text { (https://creativecommons.org/licenses/by/4.0/) }\end{aligned}$
}

\begin{abstract}
ABSTRAK
Bertempat tinggal jauh dari pusat kota dan tidak adanya akses jalan raya membuat peranan kapal sangatlah penting bagi penulis dan masyarakat dusun Bumbung dipedalaman pulau Kalimantan. Ketergantungan terhadap kapal sangatlah dirasakan penulis dalam menjalani aktivitas sehari-hari. Dari ketergantung tersebut menimbulkan kedekatan yang intim diantara keduanya, sehingga dalam pengkajiannya, kapal yang memiliki karakter dan filosofi kehidupan menjadi dasar penulis untuk mewujudkan sebuah karya. Kapal menjadi subject matter dalam penciptaan karya lukis. Kapal bukanlah sebagai inti sebenarnya, melainkan metafora dari kompleksitas perjalanan kehidupan manusia. Penulisan ini bertujuan untuk mendeskripsikan konsep, proses visualisasi, teknik, media dan bentuk dalam pembuatan karya seni lukis yang mengambil tema Kapal Sebagai Ide Visual Karya Seni Lukis. Dalam karya Tugas Akhir ini penulis ingin mencari sebuah jawaban atas kesinambungan yang terdapat dalam karya-karya sebelumnya, menjelaskan keterikatan apa yang dimiliki penulis dengan kapal. Mengambil bagian dari pengalaman empiris dan peristiwa-peristiwa yang terjadi di masyarakat yang penulis amati dan di latarbelakangi oleh perbedaan pola pikir pelaku kebudayaan dalam menjalani kehidupan baik sebagai individu ataupun sosial. Metode yang digunakan penulis yaitu: Metode eksplorasi dari berbagai fakta atau kejadian untuk mencari dan memilih tema yang sesuai dengan konsep penciptaan lukisan, metode interpretasi secara mendalam untuk mencari makna dan ide-ide baru. Penulis menggunakan pendekatan kontemporer yang didalamnya terdapat gaya realis dan surealis serta menampilkan simbolisme, metafora, transformasi bentuk, dan deformasi bentuk.
\end{abstract}

Kata kunci: kehidupan manusia, simbolis kapal

\begin{abstract}
Staying away from the city and the absence of highway access makes the use of ship become very important for the writer and the people of Bumbung village in the island of Borneo. Dependence on the ship is very felt by the writer in the daily activities. It affects intimate relation between the writer and the people in his village, so in his study, the ship which has the character and philosophy of life. It become the basic of the writer to realize an art work. The ship became the subject matter in creation of painting work. The ship is not as the real core, but the metaphor of the complexity of the journey of human life. This writing aims to describe the concept, the process of visualization, techniques, media and forms in the manufacture of painting that takes the theme Ship as the Visual Idea of Painting Work. In this final project, the writer wants to find an answer of continuity that contained in previous works, explaining attachments of the writer with the ship. Taking part of the empirical experience and events occurring in the society that the writer observed and the reason of differences thinking of cultural actors in living life as individual or social. The method used by the writer are: exploration methods from various facts or events to find and to choose a theme which appropriate with the concept of painting creation, methods of interpretation in depth to find new meanings and ideas. The writer uses a contemporary approach in which there is a realist and surrealist style and displays symbolism, metaphor, shape transformation, and form deformation.
\end{abstract}

Keyword: human life, ship symbolic.

\section{PENDAHULUAN}

Kehidupan manusia tidak pernah terlepas dari unsur-unsur budaya, pendidikan, sosial dan politik. Dalam kehidupan sehari-hari, unsur yang paling melekat adalah permasalahan sosial. Permasalahan sosial yang terjadi dalam kehidupan manusia sangat beragam, seperti pencitraan seseorang yang tercipta dari anggapan masyarakat atau tercipta oleh kondisi yang ada, tidak adanya keseimbangan antara hak dan 
kewajiban, tersingkirnya komunitas kecil dan masih banyak lagi. Permasalahan pokok yang sering terjadi di masyarakat adalah permasalahan ekonomis, kebutuhan yang harus terpenuhi setiap harinya. Dengan rendahnya sumber daya manusia dan tekanan ekonomi yang rendah, masyarakat sangat rentan terhadap hasutanhasutan ataupun suatu isu yang selalu berupa imingiming keuntungan dibaliknya yang kadang lupa terhadap dampak jangka panjangnya. Ernawati mengemukakan dalam tulisannya bahwa Perkembangan karya seni menunjukkan dinamika yang menarik, hal yang dekat dengan keseharian dapat menjadi konsep yang menarik dalam proses penciptaam karya seni.

Ada satu peristiwa yang terjadi di kampung halaman penulis beberapa tahun yang lalu, labih tepatnya 2015 awal. Satu isu yang disampaikan ke masyarakat bahwa akan ada satu perusahaan yang masuk untuk membuka lahan sawit dan pihak perusahaan tersebut menawarkan harga yang bagi masyarakat terbilang angka yang cukup besar jika mereka mau menyerahkan lahannya. Dari isu tersebut timbullah kekacauan dimana-mana, kekacauan antara kelompok satu dengan yang lain, antara kampung yang satu dengan kampung yang lain diakibatkan karena perebutan tanah yang diakui. Dari dulu sampai sekarang masyarakat pedalaman ditempat asal penulis memang tidak ada surat tanah yang sah, pembagian lahan atau kepemilikan itu berasal dari turun temurun, sehingga sulit untuk memastikan kepemilikan lahan. Dari hasil musyawarah yang tidak menemukan titik temu akhirnya memicu keributan yang ditandai dengan penyerangan satu kelompok kampung yang satu menyerang kampung yang lain dengan membakar lahan kampung tersebut, begitu pula sebaliknya. Pada saat itu penulis sudah merantau ke jogja untuk kuliah dan hanya pulang kampung setahun sekali. Secara kebetulan ketika peristiwa-peristiwa penyerangan dan pembakaran lahan yang terjadi saat itu penulis berada di kampung, sehingga penulis merasakan betul suasana kampung yang sangat mencekam. Banyak sekali perubahan atau dampak yang diakibatkan permasalahan ini, seperti hubungan sosial masyarakat satu dengan yang lain menjadi renggang, aktivitas berpergian kehutan untuk berladang, mencari sayur, berburu dan lain-lain juga menjadi tantangan dengan perasaan yang was-was terhadap ancaman-ancaman dari kelompok-kelompok.

Peristiwa-peristiwa yang timbul akibat permasalahan sosial dalam kehidupan masyarakat seperti pemaparan diatas merupakan salah satu contoh masalah yang menggugah penulis untuk memvisualisasikannya dalam bentuk karya lukisan. Dari visualnya sendiri, penulis menggunakan kapal sebagai metafor dalam merepresentasikan fenomena yang terjadi di lingkungan masyarakat tempat penulis berasal. Bertempat tinggal jauh dari pusat kota dan tidak adanya akses jalan raya membuat peranan perahu atau kapal sangatlah penting bagi masyarakat dusun bumbung di pedalaman pulau Kalimantan.
Ketergantungan akan kapal sangatlah dirasakan dalam menjalani aktivitas keseharian, dari ketergantungan tersebut menimbulkan kedekatan yang intim diantara keduanya. Bagi penulis, kapal adalah simbol perjalanan, perjalanan hidup penulis sendiri ketika lahir dan besar di desa, kemudian melanjutkan pendidikan SMA di kota dan sekarang merantau kuliah di pulau Jawa lebih tepatnya di Yogyakarta. Dari perpindahanperpindahan ini, penulis banyak belajar menempatkan diri dengan banyaknya perbedaan-perbedaan tradisi di tempat penulis tinggal dan pasti banyak pula masalahmasalah yang penulis hadapi dari benturan-benturan tadisi dan kebudayan itu. Sahingga pada akhirnya penulis memilih perahu atau lebih tepatnya bagianbagian kapal sebagai subject matter dalam berkarya.

Bagi penulis, kapal yang berlayar di lautan adalah representasi dari manusia yang menjalani hidup, berbagai rintangan dan halangan yang dihadapi kapal saat berlayar sama halnya dengan kehidupan manusia yang selalu dilanda banyak masalah, dari permasalahan kecil hingga permasalahan yang rumit sekalipun dialami oleh setiap manusia. Dari peroses perjalanan hidup itu sendiri, penulis mencoba untuk menangkap beberapa peristiwa, baik itu peristiwa yang terjadi dilingkungan sekitar ataupun peristiwa yang dialami oleh pribadi penulis yang nantinya di visualisasikan dalam bentuk karya lukisan.

\section{Rumusan Ide Penciptaan}

Dalam berkarya seni lukis, ide merupakan aspek dasar yang perlu untuk diwujudkan dalam bentuk karya seni yang berhubungan dengan pemikiran dan konsep seorang pelukis. Ide ataupun konsep sangat diperlukan untuk mendukung proses pembuatan karya oleh pelukis itu sendiri. Penulis menjadikan kapal sebagai dasar penciptaan karya karena menurut penulis adanya kesamaan dan keunikkan gagasan tentang fungsi kapal dengan perjalanan hidup manusia. Penulis menjadikan kapal sebagai subject matter mengenai suatu perjalanan hidup yang tidak terlepas dari pengalaman empiris sebagai visual penciptaan karya. Dalam penelitian ini, penulis merumusan beberapa pertanyaan yaitu:

1. Apa korelasi kapal dengan peradaban masyarakat desa Bengkawan?

2. Bagaimana merepresentasikan ide yang bersumber dari pengetahuan dan pengalaman empiris penulis akan kapal sebagai ungkapan metaforis dalam lukisan?

\section{Originalitas}

Orisinalitas pada penciptaan seni menjadi hal utama dari apa yang ingin diwujudkan melalui media seni lukis yang kiranya dapat menjadi ciri khas dari karya seni itu sendiri. Sebelum mewujudkan karya, ada hal-hal yang memantik terwujudnya sebuah ide seperti karya-karya terdahulu sehingga menumbuhkan inspirasi yang dapat dijadikan referensi baik visual atau kesesuaian ide. Pada dasarnya orisinalitas merupakan sesuatu yang harus melekat pada setiap karya seni 
hingga menjadikan sebuah karya memiliki nilai khusus yang dapat membedakan pada karya seni lainya. Dalam hal ini, karya seni diciptakan bukan hasil dari meniru karya-karya orang lain yang pernah ada sebelumnya, melainan kerya seni itu memiliki keotentikan dari seniman yang menciptakannya. Menurut Susanto (2011:284), orisinalitas pada sebuah karya adanya keotentikan, serba baru menurut bentuk, konsep, maupun temanya, sehingga ada perbedaan dari karyakarya tradisional, klasik atau karya-karya lain yang telah dikenali, artinya karya tersebut bukan jiplakan atau tiruan.

Dalam menciptakan karya, penulis terinspirasi oleh seniman asal Banyuwangi yaitu Mozes Misdy. Beliau lahir di daerah Banyuwangi pesisir sehingga banyak karya-karyanya yang bertemakan nelayan ataupun lukisan-lukisan dengan objek kapal laut. Di Indonesia, nama Moses tercatat sebagai salah satu pelopor yang mengenalkan teknik palet dalam melukis, yaitu tidak menggunakan kuas melainkan pisau palet. Kekhasan dari teknik ini, penikmat lukisan seperti disuguhkan lukisan tiga dimensi, dimana dalam lukisan itu terdapat tonjolan serupa relief yang dioleskan dengan pisau palet. Perbedaan karya penulis dengan karya Mozes terletak pada upaya penulis dalam bermain persepsi dengan menyusun berbagai tanda visual bagian-bagian kapal untuk merepresentasikan fenomena yang terjadi, baik citra-citra alam maupun manusia. Penulis membuat karya dengan pendekatan realis dengan mengambil objek bagian-bagian kapal yang difoto dengan tekhnik cose up, kemudian beberapa hasil foto digabungkan dengan Adobe Photoshop untuk membuat visual sesuai konsep yang ingin diciptakan.

\section{Tujuan dan Manfaat}

1. Tujuan

Tujuan dan manfaat dari penelitian ini yaitu :

a. Memaknai kapal bukan sekedar alat transportasi, tetapi kapal sebagai simbol perjalanan hidup.

b. Mendokumentasikan kapal sebagai arsip dalam melihat perubahan yang terjadi di desa Bengkawan puluhan tahun kedepan.

c. Menggali potensi kreatif secara tekhnis maupun konseptual yang pada akhirnya penulis dapat menemukan kecenderungan yang spesifik dan otentik dalam proses berkarya.

2. Manfaat

a. Karya ini diharapkan mempu menyampaikan pesan-pesan tentang menggugah kesadaran diri untuk bertindak harus mempertimbangkan jangka Panjang dampaknya.

b. Karya ini mampu memberi informasi dan referensi dalam melihat potret kehidupan masyarakat desa Bengkawan khususnya.

\section{Tinjauan Visual}

Kajian sumber penciptaan merupakan bagaian dari proses penciptaan karya seni yang membahas perihal berbagai sumber yang menginspirasi serta menunjang gagasan perwujudan karya. Hal tersebut bisa lahir dari fenomena alam, lingkungan sosial, budaya, dan bahkan karya-karya yang pernah ada. Dalam kajian ini, penulis melakukan tinjauan dari segi visual dalam membuat karya. Ide bentuk merupakan persoalan pemilihan metafor sebagai tanda untuk menyampaikan sesuatu lewat karya. Memilih sebuah tanda untuk untuk menyampaikan pesan melalui karya seni tentunya membutuhkan ketepatan dalam pemilihan tanda itu sendiri, karena tanda akan diamati dan dibaca langsung oleh audience. Hal ini sesuai dengan yang disampaikan M. Dwi Marianto (2002: 63) tingkat bahasa visual simbolik sangat identik dengan konsep symbol Pierce yang mensyaratkan orang untuk mempelajari konvensi kultural agar bias membaca dan memahaminya.

Dari hasil pencarian literatur dan pengumpulan informasi yang dilakukan, penulis memutuskan kapal sebagai tanda dalam menyampaikan pesan melalui karya lukisan, kapal sebagai sumber metafora penulis dalam merepresentasikan kehidupan pribadi dan masyarakat desa Bengkawan. Dalam hal ini, penulis mengamati beberapa karya seniman terdahulu yang juga mengangkat kapal sebagai subject metter dalam menciptakan karya untuk dijadikan referensi dalam berkarya, namun karya-karya tersebut terdapat perbedaan yang kiranya memberi peluang untuk proses perwujudan karya penulis sendiri. Berikut ini adalah beberapa karya seniman terdahulu yang menggunakan kapal sebagai subject matter dalam menciptakan karya yang penulis jadikan sebagai acuan dalam proses kreatif:

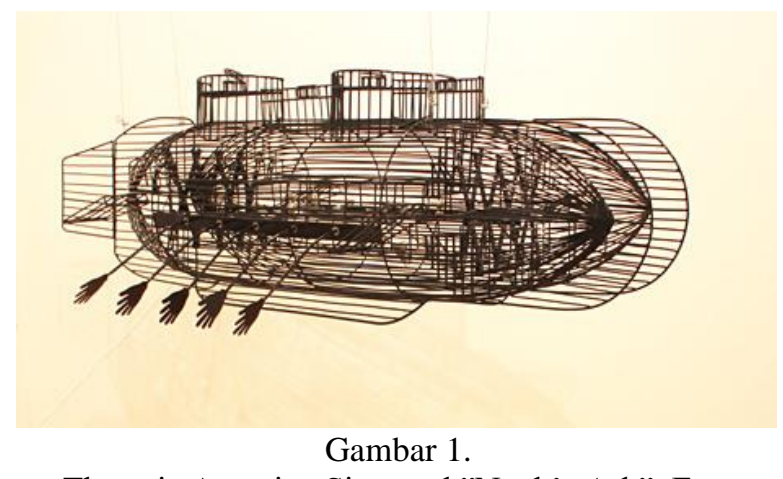

Theresia Agustina Sitompul.'Noah's Ark", Eser concrete steel dan alumunium, $140 \times 190 \times 61 \mathrm{~cm}$, 2012.

(Sumber: indoartnow.com)

Theresia Agustina tertarik dengan gagasan untuk menuliskan ulang kisah-kisah yang ia baca dari Perjanjian Lama dan Perjanjian Baru. Agustina tertarik untuk menggambarkan secara visual narasi tersebut, mengesktremkan modus fantasi yang ia temukan di dalamnya. Dalam pandangan Agustina, seluruh kisah dalam Perjanjian Lama dan Baru mengandung gagasan 
visual yang sangat menarik terutama karena mereka banyak mendasarkan diri pada gagasan tentang mukzizat atau keajaiban, yang menantang seseorang untuk membayangkan sesuatu yang melampaui kenyataan. Menuliskan ulang narasi ini memberikan kesempatan pada Agustina untuk melihat kisah ini dalam konteksnya yang sekarang, atau mengaitkannya dengan sejarah yang berkait pada lokalitas tertentu. Salah satu instalasi yang ia ciptakan berjudul "Noah Ark (Perahu Nuh)"' dimana ia membuat versi baru dari Kapal Nuh, sebuah cerita yang sudah sangat dikenal oleh publik luas. Agustina mentransformasikan gagasan tentang Kapal Nuh dalam konteks sejarah kolonialisme di Indonesia, dengan mengisi kapal dengan bebijian dan rempah-rempah, yang selalu disebut sebagai sumber dari keinginan untuk menguasai negara tropis..

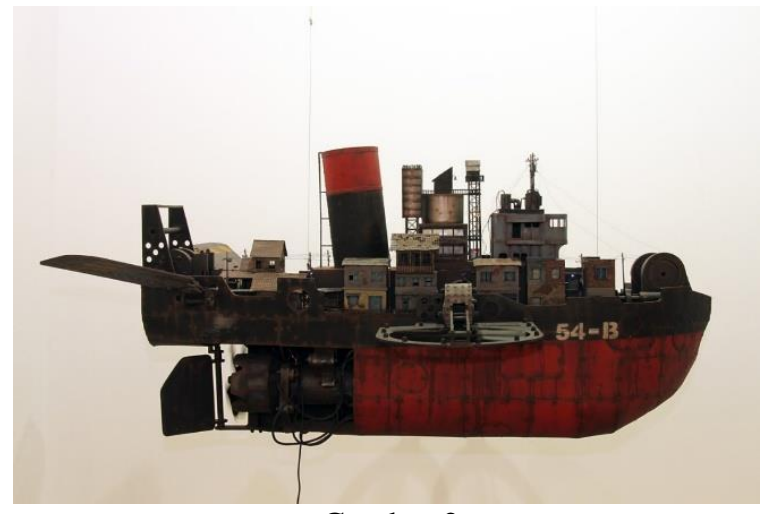

Gambar 2.

Yudi Sulistyo. "World Without Sea", Instalasi bentuk kapal dari kertas karton, 160 x 490 x 243 cm, 2013.

(Sumber: indoartnow.com)

Yudi Sulistyo merupakan seniman yang lebih sering memfokuskan dirinya drngan menciptakan karya instalasi dengan ukuran karya-karya yang relatif besar dan spektakuler. Seperti yang dilihat pada gambar 2.2 diatas, salah satu karya Yudi yang menginspirasi penulis dalam membuat karya karna adanya keasamaan antara karya penulis dengan karya Yudi yang samasama menggunakan subject metter kapal dalam menciptakan karya. Yudi menggunakan kapal sebagai symbol dalam merepresentasikan kehidupan manusia yang dapat kita lihat adanya pemukiman yang dibuatnya diatas kapal. Kapal bukan lagi diinterpretasikan sebagai kapal secara harfiah, tetapi menunjukan bahwa kapal ibarat bumi yang dihuni manusia diatasnnya (dunia tanpa daratan). Disini penulis merasa ada ruang kosong yang memberikan peluang penulis dalam membuat karya dengan subcect metter kapal, yaitu permainan persepsi dengan menggunakan bagian-bagian kapal sebagai objek yang mereprentasikan kehidupan manusia sebenarnya. Penulis tidak membuat kapal secara utuh karena menurut penulis, semua bagian-bagian kapal memiliki peranan masing-masing dalam menginterpretasikan suatu fenomena.

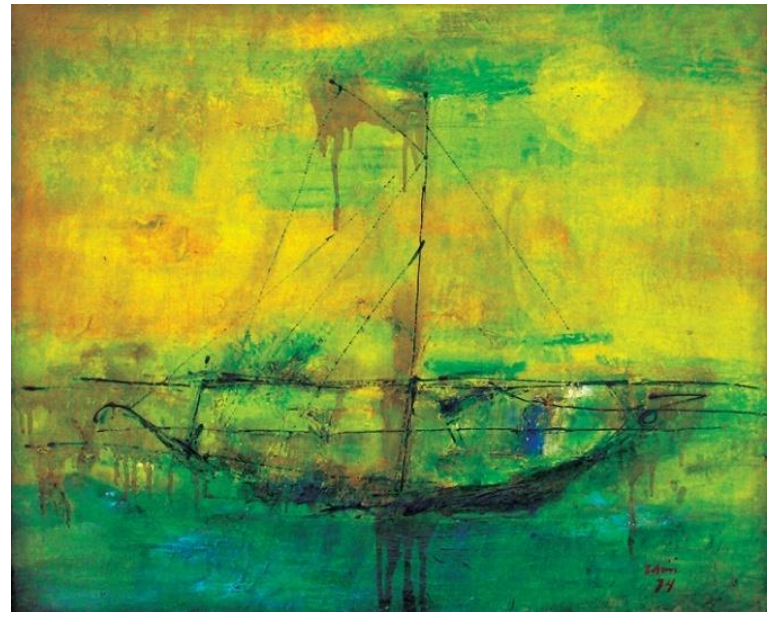

Gambar 3.

"Perahu" karya Zaini, tahun 1974

(galeri-nasional.or.id)

Dalam lukisan ini, Zaini melukiskan perahu dengan abstraksi yang menghadirkan suasana puitik, dengan sapuan-sapuan kuas yang menciptakan suasana lembut, warna dan garis dalam lukisan Zaini ternyata memunculkan objek-objek dalam kekaburan. Dengan lukisan-lukisan bernuansa lembut itulah Zaini sangat kuat menciptakan bahasa abstraksi. Lukisan "Perahu" ini, seperti kekuatan lukisan-lukisannya yang lain yaitu menyampaikan pesan misteri dari kehadiran samarsamar objeknya.

Menarik Bagi penulis untuk mengamati lukisan yang berjudul "perahu" karya dari Zaini ini, karena karya ini mengacu pada karya-karya yang akan penulis buat secara kemasan visualnya. Visual perahu yang dilukisan zaini sudah terlepas dari bentuk perahu itu sendiri dan hanya memberi kesan-kesan dalam goresannya yang menggambarkan bahwa itu perahu. Dengan perkambangannya, lukisan realis tidak lagi menjadi acuan dalam orang menilai suatu karya lukis, hal itu menarik dan sangat penting demi kemajuan dunia seni lukis sendiri.

Soedarso SP, (2006: 72) menyatakan kalau seorang seniman modern ingin melukis kuda, maka ia harus terbebas dari segala macam lukisan kuda yang pernah dilihatnya, termasuk lukisan kuda yang pernah dilukisnya sendiri. Pada saat itu ia harus mengadakan pengamatan baru karena setiap pengamatan selalu dipengaruhi dan diwarnai oleh kumpulan pengalaman yang dipunyai dan suasana kalbu yang sedang dirasakannnya, sehingga hasil pengamatannya terhadap suatu objek pada suatu saat akan berbeda dengan hasil pengamatan di saat yang lain. Apa lagi hasil pengamatan orang lain dengan koleksi pengalaman yang berbed

\section{Landasan penciptaan}

Karya seni yang dihasilkan merupakan buah perenungan dari apa yang dilihat, didengar, dan dirasakan penulis ketika melihat, mendengar dan merasakan. Karya seni merupakan hasil pengungkapan batin, perenungan, pengalaman dan pengamatan 
tentang merasakan sesuatu, menganalisis sesuatudengan rasa. Seperti yang diungkapkan oleh M. Dwi Marianto ( 2019: 243-244), Dengan rasa kita tidak hanya mengartikan realitas seperti apa adanya, dan memaparkannya seperti apa adanya secara hitam-putih, melainkan dapat pula kita memecah-mecah realitas itu menjadi remah-remah dan dalam berbagai lapisan, untuk kemudian memadukannya kembali menjadi suatu pola baru, yang bagi pelakunya sendiri akan lebih bermakna.

Karya seni diciptakan untuk mengungkapkan bentuk kegelisahan yang saat ini dirasakan penulis dan apa yang terjadi di lingkungan sekitar penulis. Menurut hasil pengamatan penulis, permasalahan yang paling sering timbul dalam kehidupan manusia adalah permasalah yang dipicu akibat kebutuhan ekonomi dan sumber daya manusia yang masih kurang. Visualisasi karya seni dilakukan sesuai dengan interpretasi penulis dalam menyikapi masalah yang terjadi. Selanjutnya, direnungkan dan divisualkan dalam bentuk karya seni dua dimensional yaitu lukisan. Seperti yang diungkapkan oleh Sulebar M. Soekarman dalam mendefinisikan makna dari soulscape yang menyatakan bahwa soulscape adalah upaya visualisasi kegelisahan transendental bagaimana mengungkapkan solusi permasalahan mendasar kemanusiaan tentang rasa kemanusiaan itu dalam meng-ada serta me-wujud sebagai sebuah karya seni ( Sulebar M. Soekarman, 2010: vi).

Timbulnya proses kreatif seni terjadi berkat interaksi antara penulis dengan lingkungannya. Sebagai proses perwujudan, karya seni memanifestasikan konteks masalah dalam konsep penciptaan. Sehingga subject matter (objek visual karya) haruslah sesuai dengan contentnya (isi/arti dari karya tersebut). Dalam berkarya penulis menitik beratkan proses kreativitasnya dengan mengacu pada pendapat Robert Pepperell.

Dalam buku The Post Human Condition, menyatakan kreativitas tidak selalu terdapat pada produksi apapun yang seluruhnya baru, karena tak bisa disangkal lagi, tidak ada sesuatu yang seluruhnya 'baru', Malahan, tindakan kreatif lebih baik dipahami sebagai realisasi transformasi-transformasi yang bermanfaat yang dihasilkan oleh gabungan unsur-unsur yang telah ada tapi sebelumnya dilihat sebagai terpisah atau tidak kompatibel (tidak harmonis atau tidak cocok). (Pepperell, 1997: 195-196)

Merujuk pada pernyataan tersebut maka objek visual atau subject matter dihasilkan melalui penyusunan penggabungan idiom visual ke dalam satu rangkaian agar sesuai dengan isi/makna/content-nya. Dimana Pemilihan idiom visual diperoleh dari perenungan terhadap setiap gagasan penciptaan. Hasil dari perenungan merupakan objek-objek visual yang selanjutnya dirangkai menjadi satu kesatuan karya.

Nilai isi seni biasa disebut dengan konsep, atau wawasan seni yang berisi cerita, tujuan, pengetahuan, dan maksud dibalik penciptaan karya seni. Nilai seni bisa juga berasal dari ide dan gagasan seniman. Dalam penciptaan karya lukis, penulis memberikan nilai isi berupa konsep pada karya lukisan yang berasal dari ide penciptaan karya yaitu perjalanan hidup.

Perjalanan hidup yang dipilih penulis dan menjadi fokus adalah pengalaman empiris penulis tentang kegelisahan-kegelisahan yang dihadapi penulis terhadap persoalan-persoalan atau permasalahan yang dihadapi manusia dalam kehidupan sehari-harinya. Pada karya lukis, penulis banyak membicarakan tentang permasalahan sosial manusia dan kapal yang digunakan penulis sebagai objek visual, dan bersinggungan secara langsung dengan penulis didalam kehidupan pribadi penulis

\section{METODE PENCIPTAAN}

Proses penciptaan seni, tidak hanya sekedar soal bagaimana mengolah rasa dan menghasilkan karya-karya yang bermuatan artistik dan estetik, proses penciptaan seni, pada dasarnya juga dapat dilihat sebagai sebuah tindakan penelitian yang mampu menghasilkan produk pengetahuan layaknya berbagai bidang lainya (sains, filsafat, teknologi, dsb). Hal ini mulai disadari terutama dalam lingkup akademis, yang didorong oleh pandangan bahwa karya seni pada dasarnya tidak lahir dari sebuah kekosongan, setiap apa yang disebut sebagai karya seni tentunya merupakan sesuatu yang dapat dipertanggung jawabkan dengan cara mampu menerang jelaskan konsep dan proses kreasinya secara jelas dan terstruktur.

Untuk itu dapat dikatakan, dalam setiap proses penciptaan seni terdapat garis besar yang terkait dengan langkah-langkah dalam proses penciptaan yang sering disebut dengan metode penciptaan. Adapun metode yang digunkan penulis dalam penciptaan ini merujuk pada lima tahapan proses kreativitas yang dikemukakan oleh Campbell (1986:18-26) yakni: tahap persiapan, tahap konsentrasi, tahap inkubasi, tahap iluminasi, dan tahap verifikasi/produksi. Kelima tahapan ini merupakan rangkaian dari setiap proses kreasi yang dialami setiap orang tidak hanya dalam wilayah seni. Hal tersebut juga dijelaskan oleh Graham Walas (dalam Damajanti,2013:68-69) bahwa terdapat empat tahapan dalam proses kreasi, yakni tahap persiapan, tahap pengeraman, tahap munculnya ilham, lalu diakhiri dengan tahap pengujian.

\section{A. Tahap Persiapan}

Tahap persiapan merupakan langkah awal yang dialami dalam proses kreasi. Tahap ini dijelaskan sebagai proses terjadinya penumpukan berbagai pembendaharaan terkait sesuatu hal yang ingin kita buat atau ciptakan sebelum hal ini terealisasikan. Pada dasarnya dalam menciptakan atau menghasilkan sesuatu tidak serta merta tercipta begitu saja tanpa adanya pembendaharaan seperti pengetahuan dan pengalaman terkait hal tersebut, sesorang menciptakan pesawat tidak mungkin seketika langsung mampu menghasilkanya tanpa dilandasi oleh berbagai 
pengetahuan dan pengalaman terkait pesawat tersebut. Dalam mencipta sesuatu, tentunya kita melewati tahap persiapan yang merupakan proses pencarian dan penemuan berbagai pengetuhan dan pengalaman (Campbell,1986:19).

Terkait dalam penelitian ini, tahap persiapan ini dialami oleh penulis ketika merasakan pentingnya kapal bagi masyarakat desa bengkawan tempat asal penulis karena kapal merupakan satu-satunya sarana yang selalu digunakan masyarakat dalam beraktivitas sehari-hari. Dan dari ide konsepnya sendiri yaitu penulis berusaha menyuarakan masalah-masalah yang terjadi di desa Bengkawan.

\section{B. Tahap Konsentrasi}

Tahap ini adalah kelanjutan dari tahap persiapan, hanya saja pada bagian ini lebih intensif. Tahap konsentrasi merupakan bagian menimbangnimbang atau melakukan pemusatan, melakukan pengujian tahap awal terhadap permasalahan tersebut yang masih bersifat trial and error. Pada tahap ini sering kali terjadi semacam pergulatan antara hasrat ingin menemukan solusi terhadap permasalahan dan berbagai permasalahan yang dihadapi pada saat proses konsentrasi. Berbagai masalah tersebut yang dapat menjadi semacam mesin pemicu rasa kecewa dan putus asa karena belum adanya solusi yang tepat yang sesuai dengan harapan (Campbell,1986:20).

Dalam proses membuat karya, memang penulis merasakan banyak kendala-kendala yang dialami, mulai dari ide bentuk yang pas untuk mewakili konsep yang ingin dibicarakan, sampai mengambil keputusan terhadap tekhnik dan bahan. Dalam tahap ini penulis biasanya melakukan eksplorasi dengan 3 hal, yaitu:

\section{Eksplorasi Visual}

Penulis menemukan bahwa visualisasi kapal sering muncul dan diangkat dalam karya seni rupa secara simbolik maupun harfiah, sangat sering ditampilkan dalam berbagai medium, teknik maupun konsep. Dalam melakukan eksplorasi visual, penulis melakukan beberapa cara, yaitu:

a. Melihat langsung proses pembuatan,

b. Menggunakan kapal dalam berakitvitas,

c. Mengamati bentuk dan karakteristik kapal,

d. Mengunduh beberapa gambar dari internet dan memotret kapal secara langsung.

e. Melihat lukisan-lukisan seniman yang menjadi referensi penulis yaitu Marcel Witte sebagai acuan dari segi warna-warna yang dia pakai, cara memadukan warna dengan objek dan menyatukan objek dengan background menjadi satu kesatuan yang utuh.

Pada proses ini, penulis melakukan pengamatan pada beberapa karya-karya senimanseniman dengan pendekatan yang sama seperti yang ingin penulis buat. Penulis juga mencari informasi lebih jauh melalui dialog dengan orang-orang yang dapat memberikan masukkan terhadap visual-visual yang akan peulis pilih sebagai objek karya yang akan penulis buat. Akhirnya, penulis ingin menciptakan karya yang dapat menvisualisasikan sebuah narasi tentang bagaimana karya lukis sebagai suatu bentuk yang artistik, namun juga membawa nilai-nilai moral, intelektual dan emosional yang terus berkembang

2. Eksplorasi Konsep

Berdasarkan hasil pengamatan dan observasi terhadap kapal, penulis menyadari adanya keterkaitan yang terjadi antara filosopi kapal dalam kehidupan manusia. Kesadaran inilah yang membawa penulis untuk lebih memantapkan konsep-konsep yang dipilih dengan mengeksplorasi konsep. Berikut ini adalah tahapan-tahapan yang digunakan dalam perancangan konsep penciptaan karya lukis:

a. Melakukan observasi tentang kapal.

b. Menetapkan hasil beberapa perenungan yang dilakukan penulis tentang pengalaman empiris maupun masalah-masalah sosial yang muncul di lingkungan sekitar.

c. Menyatukan hasil renungan dengan objek kapal.

d. Menganalisis data. Data yang dianalisis berupa data primer dan data sekunder.

1. Data Primer

a. Hasil observasi pada karakter dan bentuk kapal,

b. Permasalahan yang ada di lingkungan penulis,

c. Hasil perenungan pengalaman empiris.

2. Data Sekunder

a. Hasil observasi tentang kapal dari buku,

b. Hasil diskusi yang dilakukan penulis dengan beberapa orang tentang kapal dan berbagai kaitannya,

c. Mengumpulkan gambar kapal sebagai referensi menciptakan karya seni lukis.

Dari tahapan-tahapan tersebut, terciptalah sebuah konsep penciptaan karya seni lukis yaitu dengan mengolah kapal dengan hasil renungan penulis sehingga menghasilkan pemaknaan baru.

3. Eksplorasi teknik

Ada banyak teknik melukis dengan menggunakan cat acrylic dan tekhnik yang paling sering penulis gunakan pada saat melukis, yaitu :

a. Teknik blok, cat yang langsung dari tube dengan tambahan sedikit air, teknik ini digunakan untuk sapuan dengan efek blok dan cepat menutupi bagian yang ingin diblok rata.

b. Teknik hisap, menghisap cat yang sudah di sapukan di kanvas dengan kain atau benda lain yang memiliki daya hisap untuk menimbulkan efek tekstur. Biasanya tekhnik ini dilakukan selagi cat masih dalam keadaan basah.

c. Tekhnik transparan, menggunakan tambahan air yang lebih banyak supaya sapuan kuas menjadi lebih encer di atas permukaan warna lain.

\section{Tahap Inkubasi (pengeraman)}

Tahap inkubasi adalah sebuah kondisi dimana kita justru terlepas dari berbagai tuntutan terhadap 
permasalahan tersebut, pada tahap ini kita benar-benar mencoba untuk tidak memaksa pikiran untuk harus menemukan penyelesaian masalah. Bahkan dapat dikatakan, pada tahap ini kita mencoba untuk 'membuang' sementara hal-hal yang berkaitan dengan masalah yang dihadapi. Tindakan ini dapat kita lakukan dengan cara liburan atau melakukan hal-hal yang kiranya menimbulkan perasaan yang menyenangkan dan membuat pikiran menjadi rileks (Campbell,1986:21).

Wallas (dalam Damajanti, 2013:68) menjelaskan bahwa pada tahap ingkubasi (pengerman) inilah . yang merupakan tahap paling kontrofersial karena justru pada tahap inilah bagian bawah sadar/prasadar mengambil alih dan memecahkan persoalan. Dalam alam bawah sadar/bawah sadar inilah segala macam data, informasi, dan pengalaman saling terkait dan terformulasikan menjadi sebuah solusi terhadap masalah. Karena yang bekerja adalah bawah sadar,/ prasadar, seringkali solusi-solusi tersebut muncul secara tiba-tiba ketika sedang tidak memikirkanya.

Tahap inkubasi (pengeraman) inilah yang tentunya dapat menjelaskan adanya rasa jenuh dan bosan dalam diri penulis dalam mencari solusi terhadap permasalahan terkait dengan kapal sebagai metafora. Tahapan ini adalah sebuah tahap dimana pikiran kita membutuhkan waktu untuk istirahat dan membiarkan alam bawah sadar/prasadar untuk mengambil peran dalam menemukan pemecahan masalah. Alam bawah sadar tersebut bekerja disaat pikiran kita sedang tidak berada dalam tekanan apapun, meskipun pikiran kita sedang tidak terfokus pada masalah tersebut, namun ia selalu siaga terhadap segala kemungkinan yang akan muncul.

\section{Tahap Iluminasi}

Tahap ini adalah tahap yang sangat ditunggutunggu dalam proses penciptaan, dimana pada tahap ini seringkali 'ilham' yang bersifat penerangan terhadap berbagai permasalahan atau segala solusi yang menyelesaikan perkara muncul secara tiba-tiba layaknya sebuah kilat. Hal ini bukan tanpa sebab, ia dapat dipahami sebagai hasil dari proses inkubasi (pengeraman) yang dilakukan oleh bawah sadar/prasadar yang mungkin menghabiskan waktu berbulan-bulan bahkan bertahun-tahun sampai akhirnya melahirkan kesimpulan-kesimpulan yang dapat mencerahkan (Campbell,1986:23-24).

Adanya tahap iluminasi juga pernah dialami penulis dalam proses berkarya. Sebuah solusi terhadap permasalahan terkait bagaimana merealisasikan karya yang berkaitan dengan tema Kapal sebagai metafor kehidupan masyarakat desa Bengkawan. Konsep tersebut tiba-tiba hadir begitu saja pada saat peneliti sedang dalam kondisi tidak memikirkan hal tersebut. konsep itu hadir bagaikan lampu yang tiba-tiba menyala dan menerangi ruangan yang sebelumnya dalam kondisi gelap gulita sehingga kita dapat melihat dengan jelas seluruh isi ruangan tersebut.
Datangnya ilham (iluminati) ini bukanlah sesuatu yang takbisa dijelaskan, hal ini dapat dipahami sebagai buah dari proses kerja alam bawah sadar kita yang bekerja dan selalu siap terhadap berbagai informasi dan data yang kemudian dapat menghasilkan kemungkinan yang baru.

\section{E. Tahap Verifikasi/produksi}

Tahap terakhir dalam proses kreatif adalah verifikasi atau tahap produksi. Dalam penciptaan seni, tahap ini adalah kegiatan mentransformasikan konsep yang berupa' ilham' tadi menjadi sebuah karya seni. Namun, datangnya ilham berupa konsep "Kapal Sebagai Sumber Inspirasi Dalam Penciptaan Karya Seni Lukis" tersebut bukan merupakan sebuah akhir dari proses kerja kreatif, atau tahap verifikasi tidak hanya soal mentransformasikan konsep kedalam bentuk saja, ilham tersebut masih membutuhkan analisis secara mendalam untuk mencari kemungkinankemungkinan lainnya. Maka dari itu, tidak menutup kemungkinan dalam prosesnya, kita akan kembali pada tahap-tahap awal sebelumnya (tahap persiapan, dan konsentrasi) sehingga segala masalah-masalah yang terkait dengan ide penciptaan dapat diselesaikan dengan sepenuhnya.

Menurut Wallas (dalam Damajanti, 2013:69), tahap verifikasi atau pengujian ini adalah tahap penyempurnaan ide. Pada tahap ini seluruh kontrol telah diambil alih oleh pikiran logis yang bekerja secara sadar dalam mengelaborasi masukan dari alam bawah sadar sebelumnya. Adapun prosesproses dalam tahap verifikasi atau produksi tersebut adalah sebagai berikut:

1. Persiapan bahan:
a. Kanvas
b. Cat Acrylic
c. Air Mineral

2. Persiapan Alat:
a. Alat tulis (Kapur dan Pensil)
b. Kuas
c. Wadah Palet
d. Kain Lap

3. Rancangan Kerja

Dari semua data dan informasi hasil dari menganalisis kemudian direpresentasi kedalam bahasa visual dalam bentuk sketsa-sketsa kasar. Pembuatan sketsa dikerjakan pada media kertas. Sketsa yang dibuat disesuaikan dengan konsep yang diangkat pada tiap-tiap karya. Dari beberapa sketsa yang telah dibuat penulis, kemudian diseleksi dan menghasilkan beberapa sketsa. Setelah terkumpul sketsa-sketsa, penulis melakukan pengambilan foto dan melakukan editing menggunakan aplikasi adobe photoshop untuk menggabungkan beberapa foto yang di jadikan satu frame sehingga menjadi sketsa matang yang kemudian menjadi acuan dalam penciptaan karya lukis. Salah satu contoh sketsa dari karya penulis adalah sebagai berikut: 1. Sketsa pensil 


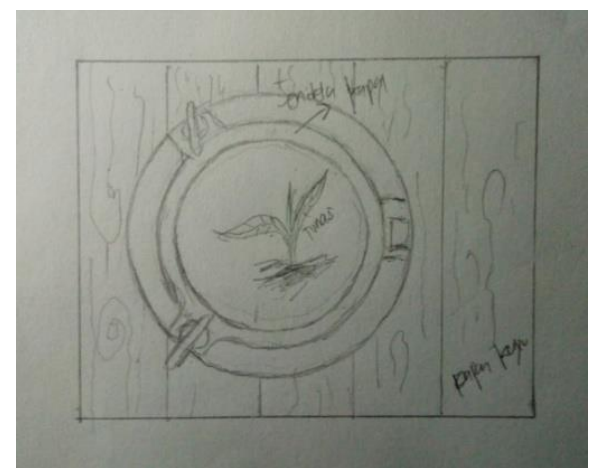

Gambar 4.

Sketsa pensil

(Dokumen Penulis)

Gambar di atas merupakan sketsa lukisan pertama. Seketsa kasar dibuat kasar dengan meletakan beberapa idiom. Agar tidak lupa, pada setiap bagian sketsa ditulis keterangan gambar.

\section{Sketsa pengeditan}

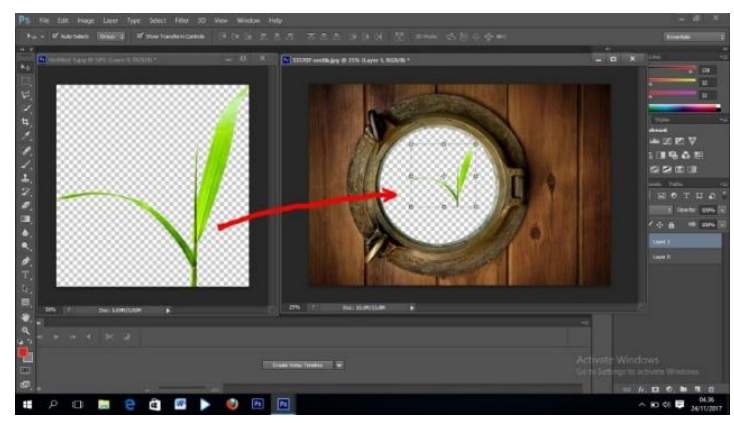

Gambar 5.

Editing penggabungan dua objek foto

Proses editing ini dilakuan untuk menghilangkan bagian dari foto yang tidak diinginkan dan menggabungkannya dengan foto lain. Seperti terlihat di gambar 3.9, penulis menggabungkan foto jendela kapal dan foto tanaman yang masih tunas menjadi satu frame, dan foto hasil pengeditan ini yang nantinya menjadi sketsa matang sebagai acuan dalam penciptaan karya lukis.

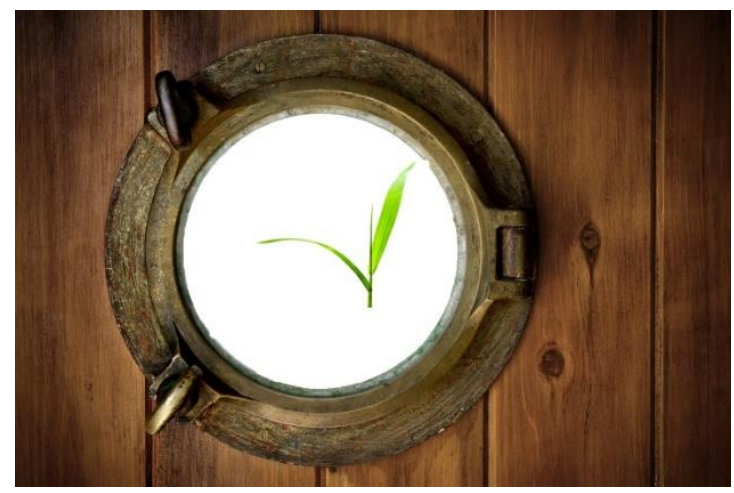

Gambar 6.

Hasil akhir editing menggunakan photoshop (Dokumen Penulis)

\section{HASIL DAN PEMBAHASAN}

\section{Tahap Perwujudan}

Konsep dan desain yang sudah dipilih kemudian di realisasikan dalam bentuk karya lukis di kanvas. Berikut ini adalah proses realisasi beberapa karya penulis:

1. Membuat Sketsa

Berbeda dengan proses pada karya-karya sebelumnya, penulis tidak mengawali denan membuat background tapi langsung membuat sketsa objek pada kanvas menggunakan pensil. Pembuatan sketsa juga harus benar-benar matang secara bentuk dan proporsinya mengikuti foto yang sudah di edit menggunakan photoshop. Seperti pada karya "kendali Diri" saat penulis membuat kemudi kapal, bentuk lingkaran pada jendela kapal juga dibuat dengan menggunakan jangka sebagai alat bantu dalam mencapai bentuk bulat yang sempurna.

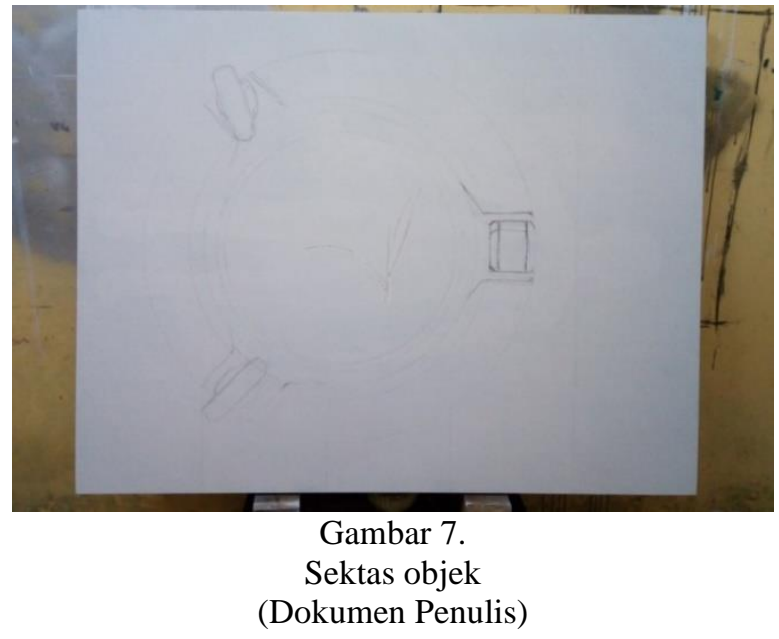

2. Mewarnai sketsa

Selanjutnya masuk pada proses melukis objek dengan mewarnai sketsa menggunakan cat acrylic. Penulis mewarna sketsa secara keseluruhan mengikuti warna pada objek aslinya dengan menentukan gelap terang pada objek. Setelah semua bagian diberi warna dan gelap terang udah tercapai, penulis membuat kontur tegas agar bentuk dari objek lebih jelas dan menegaskan intensitas warna gelap terang agar objek lebih terlihat berdimensi. 


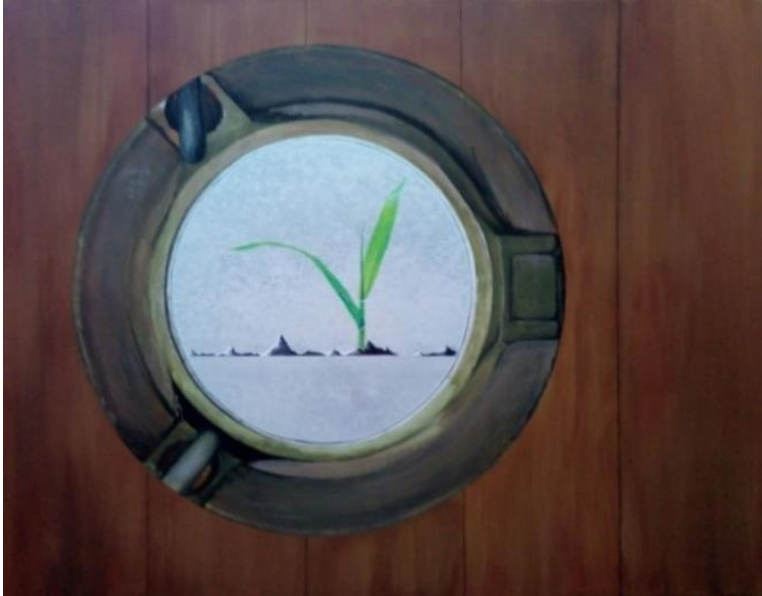

Gambar 8.

Mewarnai sketsa

(Dokumen Penulis)

\section{Penyelesaian akhir}

Tahap terakhir dalam pembuatan karya ini penulis mendetailkan serat pada kayu dinding kapal menggunakan kuas lancup berukuran kecil agar serat kayu lebih terlihat seperti pada kayu aslinya. Mendetail semua bagian pada objek dari bentuk dan warna objek dengan mengatur intensitas cahaya gelap terang pada objek secara keseluruhan. Sentuhan terakhir adalah membuat bayangan objek agar objek terlihat lebih nyata dan berdimensi seperti objek aslinya. Selanjutnya penulis melakukan mengevaluasi lukisan baik secara artistik maupun estetikanya, terutama dari segi komposisi. Jika masih ada komposisi yang kurang tepat, lukisan diperbaiki kembali untuk memperbaiki komposisinya. Pada tahap ini juga sangat diperlukan kemampuan teknik, olah rasa, serta pengalaman estetik. Sebagai tahap terakhir pembuatan lukisan adalah mencantumkan tanda tangan serta tahun pembuatan di pojok kanan atau kiri bawah lukisan.

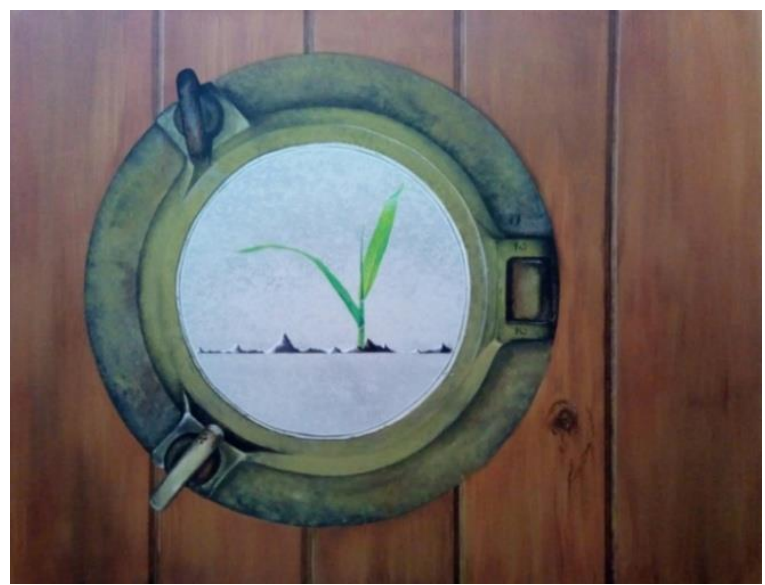

Gambar 9.

Hasil Akhir

(Dokumen Penulis)

\section{Analisis Karya}

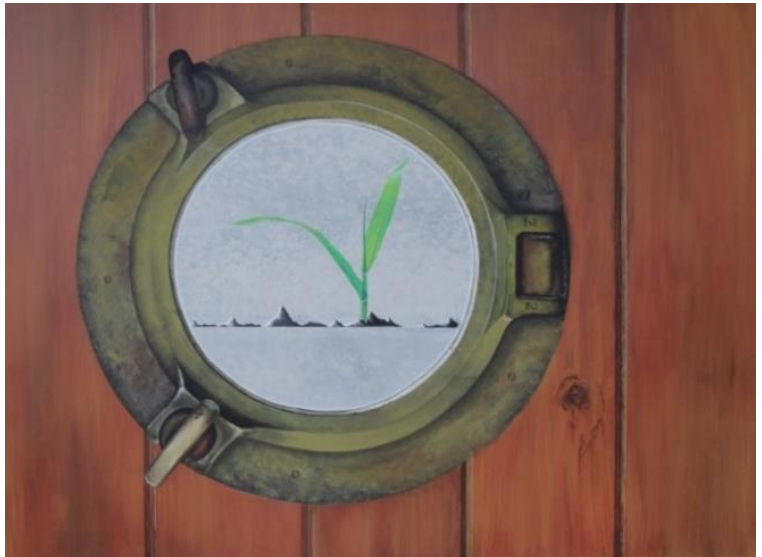

Gambar 10 .

"Tragis"

$130 \times 100 \mathrm{~cm}$

Acrylic on Canvas

2017

(Dokumen penulis)

\section{Aspek Artistik (Deskripsi)}

Karya dengan judul "Tragis”, dalam penggambaran visualnya tampak dari dalam kabin kapal sebuah jendela berbentuk lingkaran dengan susunan papan kayu yang adalah badan kapal. Pada jendela terlihat gunung yang diantaranya tumbuh tunas, warna yang digunakan sesuai dengan warna asli objek. Penggunaan warna seperti cokelat pada dinding kapal untuk membuat kesan kayu, dan jendela yang berwarna hijau dicampur warna coklan untuk membuat kesan kusam pada besi. Warna background tunas sendiri dibuat dengan warna putih dan hitam untuk menghasilkan warna abu-abu, agar warna hijau dari tunas muncul sebagai center of interest-nya.

\section{Aspek Estetis}

Karya ini memaparkan sebuah harapan dimasa depan yang dibenturkan dengan peristiwa-peristiwa yang terjadi saat ini. Semakin maraknya pembangunan membuat banyak hutan yang di babat dan dijadikan lahan pembangunan. Terlihat pada visual tunas yang tampak pada lingkaran jendela, sebagai metafor dari bagimana kapal membawa manusia dimasa depan dan pemandangan dari luar jendela tampak tumbuh satu tunas yang adalah harapan. Tragis sebagai judul sendiri mengartikan suatu harapan yang sebenarnya adalah kondisi yang menyedihkan yang akan terjadi di masa depan. Keserakahan manusia untuk memperkaya diri tanpa memikirkan efek atau dampak dari apa yang dilakukannya. Layaknya pepatah dari Mahatma Gandhi, “ Earth provides enough to satisfy every man's need, but not every man's greed

\section{PENUTUP}

Melalui karya-karya yang penulis buat, penulis dapat menarik kesimpulan bahwa penulis bermaksud ikut menyampaikan berbagai macam pandangan, pendapat, pemikiran dan keluhan manusia 
dalam menghadapi realitas kehidupan. Hal tersebut dilakukan penulis karena pada kenyataannya masalahmasalah sosial manusia sangatlah komplek. Permasalahan sosaial yang begitu banyak membuat penulis tergerak ikut menyuarakannya lewat karya lukisan..

Dari proses penciptaan karya seni yang telah menghasilkan beberapa karya, penulis juga dapat mengemukakan beberapa kesimpulan :

1. Hasil karya seni lukis kapal menjadi subject matter yang mendasari ide atau gagasan "Perjalanan Hidup" dapat di gunakan untuk menyampaikan gagasan dan ekspresi penulis sebagai media apresiasi untuk kalangan khusus maupun umum.

2. Penulis menjadikan kapal menjadi subject matter yang mendasari "Perjalanan Hidup", sebagai media mengekspresikan ide-ide atau gagasan penulis untuk menciptakan kepuasan, baik bagi orang lain dan diri sendiri.

3. Dengan melakukan perenungan atau kontemplasi melalui pengalaman sehari-hari, berarti mengharuskan penulis untuk berpikir kritis, berpikir lebih luas dan dalam dari biasanya, lalu mempertimbangkan dampaknya dengan perasaan yang menjadikan penulis lebih bijaksana dalam menyikapi masalah.

Adapun dalam proses penciptaan karya, penulis menemukan beberapa hal yang berkaitan dengan teknik berkarya, yaitu:

1. Dalam pengeksekusian karya pada kanvas, sketsa atau rancangan tidak lagi menjadi hal yang baku lagi, karena selama proses berkarya akan muncul banyak sekali pengembangan-pengembangan yang sebelumnya tidak terencanakan.

2. Penulis menemukan pencampuran dari beberapa warna untuk mendapatkan warna khusus tanpa meninggalkan unsur harmonis, yaitu menyampurkan semua warna primer salah satu dengan mengatur intensitas warna itu sendiri dalam menyelesaikan karya seni.

3. Tekhnik transparansi untuk menyatukan gelap terang, garis dan warna menjadi satu kesatuan untuk mencapai gradasi yang sempurna.

4. Penulis bisa menemukan gaya khas yaitu surealistik sebagai gaya pribadi penulis.

5. Kejujuran dan ketulusan hati sangat mempengaruhi hasil dari karya-karya lukis yang diciptakan.

Karya seni lukis terdiri dari dua aspek, yaitu isi dan bentuk. Isi berkaitan dengan suatu yang ada di balik pembentukan. Sedangkan aspek bentuk, berkaitan dengan perwujudan yang dapat ditangkap dengan indera penglihatan. Dalam penciptaan suatu karya melalui proses yang diawali dengan ide atau gagasan, yang kemudian dituangkan ke dalam sebuah karya seni dan didasari pengetahuan emosional, intelektual, dan spiritual. Sedangkan karya seni itu sendiri adalah suatu benda yang memiliki nilai estetis. Pengalaman estetis dan perasaan perupa menjadi penunjang vitalitas berhasil tidaknya suatu karya. Oleh karena itu dalam pembuatan sebuah karya seni bukan hanya bentuk saja atau isi saja yang diutamakan melainkan keduanya agar karya yang dihasilkan bisa memuaskan dan berguna baik bagi diri sendiri maupun bagi orang yang menikmati.

Tetaplah menghargai sebuah karya seni dalam bentuk apapun itu, karna dengan menghargai seni yang sudah ada, manusia akan menjadi orang yang sadar akan nilai keindahan yang memang sudah ada sejak lama dan kehidupan yang kompleks, dan jadikan seni itu sendiri sebagai media untuk mengasah kepekaan indra dan rasa.

\section{DAFTAR PUSTAKA}

Campbell, David. 1986. Mengembangkan Kreativitas, Yogyakarta: Kanisius.

Darmajanti, Irma. 2013. Psikologi Seni, Bandung: PT. Kiblat Buku Utama.

Ernawati, E. (2019). Kosmologi sebagai Pijakan

Kreasi dalam Berkarya Seni (Cosmology as

the Foundation of Creation in Artwork).

INVENSI (Jurnal Penciptaan Dan

Pengkajian Seni), 4(2), 113-129.

Lapian, B. Adrian. 2011. Orang Laut Bajak Laut Raja Laut, Jakarta : Komunitas Bambu.

Marianto, M. D. 2002. Seni Kritik Seni. Yogyakarta: Lembaga penelitian ISI Yogyakarta. 2019. Seni dan Daya Hidup dalam Perspektif Quantum. Scritto Books dan BP ISI Yogyakarta.

Pepperell, Robert. 1997. The Posthuman Condition. Terjemahan Hadi Purwanto, Yogyakarta: Kreasi Wacana.

Soedarso Sp. 2006. Trilogi Seni. Yogyakarta: ISI Yogyakarta.

Sulebar M. Soekarman - AA Nurdjaman - Netok Sawiji_Rusnoto Susanto - Anton Larenz. 2010. SOULSCAPE - The Treasure of Spiritual Art. Yayasan Seni Visual Indonesia.

Susanto, Mikke. 2011. Diksi Rupa: Kumpulan Istilah dan Gerakan Seni Rupa. Yogyakarta: Dicti Art Lab \& Djagad Art House. 